\title{
Do Depreciations Really Trigger an Inflow of Foreign Direct Investment? The Case of Turkey
}

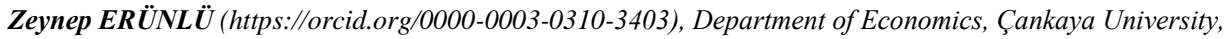
Turkey; e-mail: zeyneperunlu@cankaya.edu.tr

\section{Döviz Kuru Doğrudan Yabancı Yatırım Girişini Gerçekten Tetikler mi? Türkiye Örneği}

\begin{abstract}
In this study, the relationship between real exchange rate and foreign direct investment is examined using the Logistic Smooth Transition - Autoregressive Distributed Lag (LST-ARDL) model. Analyzing the effect of real exchange rate changes on foreign direct investment is very crucial for a developing country like Turkey which has a relatively large foreign debt stock. The estimation results show that foreign direct investment inflows to Turkey increase when Turkish Lira appreciates against the US dollar and this effect is especially strong during periods of high investment inflows. Thus, for Turkey to attract productive capital flows rather than unstable short-term portfolio flows it has to maintain a strong currency against the US dollar.
\end{abstract}

Keywords

Exchange Rate, Foreign Direct Investment, Smooth Transition Regression Model, Threshold Effect.

JEL Classification Codes : $\quad$ C22, F21, F31.

$\ddot{\mathbf{O z}}$

$\mathrm{Bu}$ çalışmada, reel döviz kuru ile doğrudan yabancı yatırımlar arasında ilişkinin varlığı, Lojistik Yumuşak Geçişli - Otoregresif Dağıtılmış Gecikme Modeli (LST-ARDL) modeli kullanılarak incelenmiştir. Reel döviz kuru değişikliklerinin doğrudan yabancı yatırımlar üzerindeki etkisi özellikle Türkiye gibi yüksek miktarda yabancı borç stoku olan gelişmekte olan ülkeler için çok önemlidir. Tahmin sonuçları, Türk Lirasının Amerikan Doları karşısında reel olarak değer kazanmasının yabancı sermaye girişini arttırdığını ve bu etkinin özellikle yüksek sermaye girişinin olduğu dönemlerde daha yüksek olduğunu göstermiştir. Bu nedenle, Türkiye'nin istikrarsız kısa vadeli portföy akımlarından ziyade üretken sermaye akımlarını çekmesi için Amerikan dolarına karşı güçlü para birimini sürdürmesi gerekmektedir.

Anahtar Sözcükler : Döviz kuru, Doğrudan Yabancı Yatırım, Yumuşak Geçişli Regresyon Modeli, Eşik Etkisi. 


\section{Introduction}

Foreign investment can be defined as the transfer of investable resources to another country by individuals and organizations (SPO, 2000: 1). It can take place in many ways. Portfolio investments are the first and the most frequently observed type of foreign investment and involve the purchase of securities. Foreign direct investments, on the other hand, are investments that are made by one or more companies in the form of partnerships.

Foreign direct investment (FDI) is classified as horizontal and vertical FDI and holdings (Karagöz, 2007). A horizontal FDI usually takes place to establish a facility in a foreign country by an investor that operates a similar facility in the investors' country of origin. The investor here aims to benefit from the unsaturated market. In this type of investment, also called "market oriented investment", the investor evades quota, transportation and other costs and restrictions. Vertical FDI, however, is called "resource oriented investment" and takes place in different forms such as investments that are close to the raw material resources or investments that are close to the consumer. Holding investments contain both vertical and horizontal FDI characteristics.

FDIs have several positive effects on the host country's economy. This type of investment will contribute to the reduction of the unemployment rate and foreign trade deficit while increasing the production level of the country in question. FDIs lead to the transfer of new technologies and thus improvement of technology inside the country. Moreover FDIs boost competitiveness of the host country by increasing labor productivity. If the host country in question is a developing country like Turkey, FDI also contributes remarkably to the development and the growth of the country.

Regarding developing countries, the abovementioned investments are of particular value in terms of external financing costs. Since the financing from international financial institutions and banks can be subject to severe conditions and repayments, the use of FDIs as a source of foreign financing positively affects underdeveloped and developing countries due to their production-oriented structures that bring modern technology to the country without any repayment. Portfolio investments, on the other hand, are short-term, unstable and more volatile financial flows that merely want to take advantage of the high real interestrate and low exchange rate arbitrage conditions of the host country. These flows can be subject to sudden stops with a slight decline in the real interest rate. However FDI is a productive investment. Contrary to portfolio investments that involve only financial capital flows, FDIs contain the inflow of modern technology, production technology know-how and business knowledge and are thus, recommended to developing countries as a source of foreign financing by various international organizations and consultants (Yılgör et al., 2011). This situation is of greater importance to fragile countries with high external financing needs, such as Turkey. Indeed, Turkey's net international investment deficit as of October 2017 topped \$ 434 billion indicating a 20\% increase compared to December 2016. Likewise the total of short-term external debt stock with a maturity of 1 year or less is $\$ 173.4$ billion by the end of October 2017. In order to meet this high level of external financing, Turkey needs 
to increase the quality of its foreign financial borrowing rather than meeting this need with hot Money.

The above-mentioned significant contributions of FDI to the host country's economy have led many researchers in the literature to try to identify the factors influencing the inflows of FDI. Of these factors, the most controversial one is the exchange rate. The relationship between the exchange rate and direct foreign capital flows is not clear. In the literature, prior to the 1970s, FDI is evaluated by trade theorists as an event related to comparative costs, especially when the factor costs of trade are not equalized (Blonigen, 1997). According to this conventional view, it is thought that the exchange rate does not affect FDIs. Similar results are obtained in various studies ${ }^{1}$. Later on, the existence of correlation between the investments and the exchange rate is explored in order to explain the brief cyclical fluctuation observed in FDI in the US economy. In many empirical studies, the depreciation of the host countries currency has been found to increase foreign capital inflows into the host country ${ }^{2}$. However limited number of studies have found that the depreciation of the host country currency relative to the home country currency decreases inflow of FDI from the home country to the host country ${ }^{3}$.

While examining the impact of the exchange rate level on FDI, two relationships can theoretically be observed; serving at a local market or re-exporting (Benassy-Quere \& Fontagne \& Lahrache-Revil, 2001: 180). If the investor aims at serving a local market in which there are trade and nontrade barriers for entering the market, FDI and trade are substitutes. As the appreciation of the local currency will cause an increase in purchasing power and as the barriers to trade tend to increase in this context, foreign direct investments will also increase. On the other case, if the investor will re-export the output from FDI, trade and FDI are complements. The real appreciation increases the relative labor costs and thus the production costs, decreases the profits of the firms and competitiveness, changes the relative wealth effect and decreases the foreign capital investments. Therefore, the country experiencing real appreciation loses regional attractiveness or superiority, as it discourages productive investment inflow.

There are conflicting findings both in the theoretical and the empirical literature on the existence and nature of the relationship between foreign exchange rate and foreign direct investment. For Turkey, the number of studies examining the relation between FDI and the exchange rate is limited. The most recent study on this subject belongs to Cambazoğlu and Güneş (2016), who use the linear cointegration method to examine the relationship between the exchange rate and FDI for Turkey covering the years 2007-2015. The authors concluded

I For detailed information see Blonigen (1997).

2 Froot and Stein (1991), Harris and Ravenscraft (1991), Swenson (1994), Klein and Rosengren (1994), Dewenter (1995), Blonigen (1997), Bayoumi and Lipworth (1998), Goldberg and Klein (1998), Ito (2000), Baek and Okawa (2001), Sazanami, Yoshimura and Kiyota (2003), Kiyota and Urata (2004) and Takagi and Shi (2011).

3 Caves (1989), Stevens (1998), Yaprakl (2006). 
that the depreciation of the national currency would increase FDIs. But such an outcome does not seem plausible for the Turkish economy. Hence, the main aim in this study is to explicitly reveal the contradictory relationship between the exchange rate and FDI in Turkey.

Within the framework of the traditional monetary transmission mechanism, it is argued that the real depreciation of the domestic currency will affect foreign trade positively and lead to revitalization of the country's economy. However, the exchange rate channel for Turkey is working in the opposite direction. When Turkish lira appreciates, the economy booms and in periods of depreciation, it enters into a stagnation period (Central Bank of the Republic of Turkey, 2013). The appreciation of the Turkish Lira increases the net value of firms and leads to an increase in resources available for production. In addition, due to the intensive use of imported intermediate goods in the production phase in Turkey, appreciation of the Turkish Lira reduces manufacturing costs and encourages production. Lastly, the real appreciation boosts domestic buyers' purchasing power and supports domestic demand. As a result, the real appreciation of the national currency encourages foreign investment into Turkey as it is embraced as a sign of a strong economy. However, the depreciation of the Turkish lira, leading to further deterioration of the existing external financing needs, increases the fragility of Turkish economy. An economy with increased financial vulnerability will not be able to attract adequate amount of FDI. Overall, the main purpose of this study is to clarify this rather controversial relationship between FDI and exchange rate in Turkey.

Although the above-mentioned empirical studies have commonly used linear models, it is observed in economic theory that many important economic variables exhibit a nonlinear structure. For instance, the downward stickiness of the prices and wages is the basic assumption of many macroeconomic models. The main macroeconomic variables, such as labor and employment, decline more during the recession periods than they increase during the expansion periods (Enders, 2010). Similarly, studies show that countries do not react to the decreases and increases in the real exchange rates or interest rates in the same manner (Çorakcı \& Omay \& Emirmahmutoğlu, 2017a; Omay \& Çorakçı \& Emirmahmutoğlu, 2017; Sollis, 2009). Policy changes, the existence of a crisis environment and the institutional changes made thereafter to recover in the future, alter the relations between the variables and the variables themselves in isolation. Accordingly, linearly estimated models are inadequate (Omay \& Hasanov, 2010). If a linear relationship is observed in empirical studies with different economic variables, linear models will certainly be used. However, as shown in this study, if there is no linear relationship between the variables examined than the alternative nonlinear models should be preferred. If not, the linear model will be misspecified.

This study examines whether a real depreciation in the Turkish Lira positively affects the FDIs. Unlike other studies related to Turkey, foreign exchange and FDI relationship is estimated using a non-linear structure. The choice of non-linear model is very important. In this study, Smooth Transition Regression (STR) is used. In this model, the change in economic variables is not immediate as in the Markov regime change model, but it is a smooth transition and it offers an infinite number of regime modeling opportunities. Another 
important issue is that the regime change variable is determined internally in the estimation process. STR models also allow the determination of the threshold value endogenously, therefore, the Threshold Autoregressive (TAR) model emerges as a special case of the Logistic Smooth Transition Regression (LSTR) (Omay \& Araz-Takay \& Eruygur \& Kılıç, 2013: 144). Due to these advantages, the relationship between the real exchange rate and FDIs is examined on monthly basis during the 2005-2016 time period using the LST-ARDL model.

In section two, the econometric methodology and the STR models are introduced. In the third section the results of the unit root, linearity and diagnostic tests are reported and discussed. Fourth section draws conclusions.

\section{Specification and Estimation of STR Models}

The smooth transition autoregressive (STAR) model for a univariate time series $y_{t}$, which is observed at $\mathrm{t}=1-\mathrm{p}, 1-(\mathrm{p}-1), \ldots,-1,0,1, \ldots, \mathrm{T}-1, \mathrm{~T}$ is given by (van Dijk, Terasvirta and Franses, 2000: 2):

$$
\begin{aligned}
y_{t}= & \left(\phi_{1,0}+\phi_{1,1} y_{t-1}+\ldots+\phi_{1, p} y_{t-p}\right)\left(1-G\left(s_{t} ; \gamma, c\right)\right) \\
& +\left(\phi_{2,0}+\phi_{2,1} y_{t-1}+\ldots+\phi_{2, p} y_{t-p}\right) G\left(s_{t} ; \gamma, c\right)+\varepsilon_{t}
\end{aligned}, t=1, \ldots, T
$$

The short representation of Eq. (2.1) is as follows:

$$
y_{t}=\phi_{1}^{\prime} x_{t} \cdot\left(1-G\left(s_{t} ; \gamma, c\right)\right)+\phi_{2}^{\prime} x_{t} \cdot G\left(s_{t} ; \gamma, c\right)+\varepsilon_{t}
$$

The weighted autoregressive structure in equations (2.1) and (2.2) can be written as (Terasvirta, 1994: 208):

$$
y_{t}=\left(\phi_{1} x_{t}\right)+\left(\phi_{2}-\phi_{1}\right) x_{t} \cdot G\left(s_{t} ; \gamma, c\right)+\varepsilon_{t}
$$

Here, $x_{t}=\left(\phi_{1,0}+\phi_{1,1} y_{t-1}+\ldots+\phi_{1, p} y_{t-p}\right)^{\prime}$ is the vector of the lagged values of the endogenous variable and when $\tilde{x}_{t}$ is defined as $\tilde{x}_{t}=\left(y_{t-1}+\ldots+y_{t-p}\right)^{\prime}, x_{t}$ equals; $x_{t}=\left(1+\tilde{x}_{t}^{\prime}\right)^{\prime}$. The set of coefficients vector can be defined as $\phi_{i}=\left(\phi_{i, 0}+\phi_{i, 1}+\ldots+\phi_{i, p}\right)^{\prime}$, $\mathrm{i}=1,2$. With the use of the above defined abbreviations, the STAR model can be rewritten briefly as in (2.4):

$$
y_{t}=\phi_{1}^{\prime} x_{t}+\left(\phi_{2}^{\prime} x_{t}\right) \cdot G\left(s_{t} ; \gamma, c\right)+\varepsilon_{t}
$$


The $\varepsilon_{t}$ 's are assumed to be a martingale difference sequence with respect to the history of the time series up to time t-1, which is denoted as $\Omega_{t-1}=\left\{y_{t-1}, y_{t-2}, \ldots, y_{t-(p-1)}, y_{t-p}\right\}$, that is $E\left[\varepsilon_{t} / \Omega_{t-1}\right]=0$ and the conditional variance of $\varepsilon_{t}$ is constant; $E\left[\varepsilon_{t}^{2} / \Omega_{t-1}\right]=\sigma_{\varepsilon}^{2}$ (van Dijk, 2000: 2). The transition function $G($.$) is a continuous function bounded between 0$ and 1 and it can be the lagged value of the endogenous variable or an exogenous variable (Terasvirta, 1994). In the studies it is often used as lagged values of the endogenous variable $\left(s_{t}=y_{t-d}, \mathrm{~d}>0\right.$ ). Also, the transition variable can be a time trend $\left(S_{t}=t\right)$. In this case, the model is a time varying parameter model showing a smooth change with time (Lin and Terasvirta, 1994) ${ }^{4}$.

Two interpretations of the STAR model are possible. Firstly, the STAR model can be thought of as a regime-switching model that allows for two regimes with the extreme values of $G\left(s_{t} ; \gamma, c\right)$ function $\left(G\left(s_{t} ; \gamma, c\right)=0\right.$ and $\left.G\left(s_{t} ; \gamma, c\right)=1\right)$ (van Dijk et al. 2000: 2). Secondly, the STAR model may allow a continuum of regimes with different $G\left(s_{t} ; \gamma, c\right)$ between 0 and 1 . In this study, the second (continuum of regimes) type of STAR model is used. Since the transition function is continuous in the range of 0 to 1 , there is a smooth, gradual transition between the regimes corresponding to the extreme values $G\left(s_{t} ; \gamma, c\right)=0$ and $G\left(s_{t} ; \gamma, c\right)=1$. The values obtained by the transition function in this range indicate different regimes. In this case there is an infinite number of regimes between the two extreme regimes. The regime is determined by the value of the $S_{t}$ variable observed at time t and the value of the $G\left(s_{t} ; \gamma, c\right)$ function. Different STR models are formed according to the values of the $G\left(s_{t} ; \gamma, c\right)$ function. The most popular function among these models is the first-order logistic function (2.5) (Teräsvirta, 1994).

$$
G\left(s_{t} ; \gamma, c\right)=\left(1+\exp \left\{-\gamma\left(s_{t}-c\right)\right\}\right)^{-1}, \gamma>0
$$

This model is defined as a logistic smooth transition autoregressive (LSTAR) model. In this equation $\mathrm{c}$ parameter is defined as the threshold. As the logistic function changes monotonically as $S_{t}$ increases, this threshold corresponds to the exact middle of the $G\left(s_{t} ; \gamma, c\right)=0$ and $G\left(s_{t} ; \gamma, c\right)=1$ regimes. The $\gamma$ parameter shows the smoothness of the 
change in the value of the logistic function (the speed of the transition function), in other words it shows the smoothness of the transition from one regime to another. As the $\gamma$ parameter increases, the regime changes very quickly when it reaches point $c$ as in the threshold autoregressive model (TAR model), while the regime transition becomes smooth as the $\gamma$ parameter becomes smaller. For very large values of the $\gamma$ parameter, the logistic function $G\left(s_{t} ; \gamma, c\right)$ approaches the indicator function and the change of the $G\left(s_{t} ; \gamma, c\right)$ function is very fast at $S_{t}=c$.

When $s_{t}=y_{t-d}$, the threshold autoregressive model becomes a self-exciting threshold autoregressive model (SETAR). When $\gamma \rightarrow 0$, the logistic transition function is close to 0.5 , and when $\gamma=0$, the transition function is equal to 0.5 . In this case, the LSTAR model becomes a linear autoregressive model. Models that allow such regime changes are suitable for modeling cyclical fluctuations. The asymmetric structure in the business cycle is modeled accurately by the LSTAR model.

The second popular transition function after logistic function is the exponential function. Such models are called exponential smooth transition autoregressive (ESTAR) models. The exponential function is shown in equation (2.6).

$$
G\left(s_{t} ; \gamma, c\right)=1-\exp \left\{-\gamma\left(s_{t}-c\right)^{2}\right\}, \gamma>0
$$

In ESTAR model, when $\gamma \rightarrow 0$ and $\gamma \rightarrow \infty$; the transition functions will be respectively $G\left(s_{t} ; \gamma, c\right) \rightarrow 0$ and $G\left(s_{t} ; \gamma, c\right) \rightarrow 1$.

The identification, estimation and evaluation process in STAR models described by van Dijk (1998:18) can be summarized as follows:

- Specify a linear autoregressive model for the time series that are under review.

- Test the null hypothesis of linearity against the alternative of STAR-type nonlinearity. If linearity is rejected, select the appropriate transition variable $S_{t}$ and form the transition function $G\left(s_{t} ; \gamma, c\right)$.

- Estimate the parameters in the selected STAR model.

- Evaluate the model using diagnostic tests. Modify the model if necessary.

- Use the model for descriptive or forecasting purposes. 
Following the estimation of the model, the suitability of the model will be tested as well. Diagnostic tests - remaining nonlinearity, remaining autocorrelation and parameter constancy - proposed by Eitrheim and Teräsvirta (1996) will be applied.

\section{Data Set and Empirical Findings}

In this study, the existence of a relationship between the real exchange rate (reer) and FDI from 2005:1 up to 2016:12 is examined. For the exchange rate variable, Consumer Price Index based Real Effective Exchange Rate $(2003=100)$ is used. All data is obtained from the Central Bank of the Republic of Turkey through the Electronic Data Delivery System.

First, the stationary of the series used in the study is tested. For this purpose, Augmented Dickey-Fuller (ADF) test is used and the data is found to be stationary. The results are shown in Table 1.

\section{Table: 1}

\section{Unit Root Tests}

\begin{tabular}{lcc}
\hline & $\begin{array}{c}\text { ADF test } \\
\text { (intercept and trend) }\end{array}$ & $\begin{array}{c}\text { ADF test } \\
\text { (intercept) }\end{array}$ \\
\hline reer $_{t}$ & $-3,126^{* *}$ & $-1,667$ \\
$f d i_{t}$ & $-9,896^{*}$ & $-9,889^{*}$ \\
\hline
\end{tabular}

Note: $\% 1, \% 5, \% 10$ critical values of ADF test are respectively $-3.51,-2.88,2.58$.

$*, * *, * * *$ indicate statistical significance at levels $1 \%, 5 \%, 10 \%$.

Since the results of the unit root tests indicate that all the variables are $\mathrm{I}(0)$, the next step is estimating the linear model to examine the relationship between exchange rate and FDI. The lags in equation (3.1) are established using Akaike Information Criteria (AIC) and Schwarz Information Criteria (SIC).

$$
f d i_{t}=\underset{(3,944)}{1,393}+\underset{(2,664)}{0,001} \operatorname{reer}_{t-8}+\underset{(1,736)}{0,171} f d i_{t-3}+\underset{(3,108)}{0,309} f d i_{t-5}+e_{t}
$$

$\mathrm{AIC}=-1,330, \mathrm{SIC}=-1,245, \mathrm{LB}(8)=5,514(0,702), \mathrm{LB}(12)=21,099(0,049), \mathrm{ARCH}(1)=7,16$ $(0,007), \operatorname{ARCH}(4)=28,193(0,000), \mathrm{D} \cdot \mathrm{W}=1,790$

*the $t$-statistics are given in parentheses.

**LB (8) and LB(12) shows the Ljung-Box Q-statistics for 8 and 12 lags.

According to the results of the linear model, it is seen that real effective foreign exchange rate has a positive and significant effect on FDI. However, the results of Engle's (1982) test for conditional heteroscedasticity for the lags 1 and 4 - ARCH (1) and ARCH (4)- test point to a heteroscedasticity problem. In addition, according to the Ljung-Box Qstatistics there is a serial correlation problem. Here, changing the lags in the linear model could not help to overcome the abovementioned problems. The existence of serial correlation and heteroscedasticity indicates that something is not taken into consideration in 
the linear model and therefore is a sign for the existence of nonlinearity between the variables.

In the third step, the linearity of the model that is estimated by ignoring the asymmetric structure that may exist between the variables should be tested. The linearity test is performed in order to figure out whether two different parameters are equal to each other in two different regimes. Null hypothesis is defined as $H_{0}: \phi_{1}=\phi_{2}$, and alternative hypothesis is defined as $H_{1}: \phi_{1, j} \neq \phi_{2, j}$, while $j \in(0, \ldots, p)$. In addition, the linearity hypothesis can also be performed by testing whether the $\gamma$ parameters in equations (2.5) and (2.6) equal to zero. If $\gamma=0$, the STR model will become a linear model. In the final case, linearity can be defined as $H_{0}: \gamma=0$ and the alternative hypothesis is $H_{1}: \gamma \neq 0$. "The linearity tests are complicated by the presence of unidentified nuisance parameters under the null hypothesis. To overcome this problem, one may replace the transition function with appropriate Taylor approximation following the suggestion of Luukkonen et al. (1988)" (Hasanov \& Omay, 2008: 2648, Terasvirta, 1994). The transition function with Taylor approximation has been transformed into a function that is linear in terms of the parameters. Thus, the hypothesis tests discussed above have become feasible for the linear model (Omay \& Hasanov, 2010: 481).

Linearity tests on LSTAR and ESTAR models can be done either individually or with a single equation (by combining the two models). In the linearity test with one equation, it is necessary to retest the selection of the transition function. In order to test the linearity hypothesis of the LSTAR and ESTAR models simultaneously third-order approximation of the transition function is used (Terasvirta, 1994). The auxiliary regression obtained from the third-order approximation of the transition function is shown in Eq. (3.2) (van Dijk 1999: 25).

$$
y_{t}=\beta_{0,0}+\beta_{0}^{\prime} \tilde{x}_{t}+\beta_{1,0} s_{t}+\beta_{1}^{\prime} \tilde{x}_{t} s_{t}+\beta_{2,0} s_{t}^{2}+\beta_{2}^{\prime} \tilde{x}_{t} s_{t}^{2}+\beta_{3,0} s_{t}^{3}+\beta_{3}^{\prime} \tilde{x}_{t} s_{t}^{3}+e_{t}
$$

Here, the error term $e_{t}$ in Taylor approximation also includes the error term $\varepsilon_{t}$ in equation (2.1). If the transition variable is not an explanatory variable, $\beta_{i, 0}, \mathrm{i}=1,2,3$ should be omitted.

Linearity tests are carried out with LM type tests. In LM type tests the alternative hypothesis is not tested. Moreover, as it can use general asymptotic theory, there is no need to test with simulation (Omay \& Hasanov, 2010: 481). Therefore, LM tests have an advantage. The LM test of equation (3.2) is shown in equation (3.3).

$$
L M=\frac{\left(S S R_{0}-S S R\right)}{\hat{\sigma}^{2}}
$$


The sum of the error squares obtained from the estimation of the linear model is $S S R_{0}$ and $S S R$ is the sum of error squares obtained from the estimation of the auxiliary model in (3.2) and the variance of the error terms is denoted as $\hat{\sigma}^{2}$. LM statistics has $\chi^{2}$ distribution. The rejection of the null hypothesis shows that a nonlinear model such as the STAR model is more appropriate. If the number of observations is small, the F test can also be used instead of the LM type test. For this reason, F test is used in this study. The F test's procedures - which yield better results compared to the LM type test in power and size- are as follows (Van Dijk, 1999: 26):

1. Estimate the model under the null hypothesis of linearity by regressing $y_{t}$ on $x_{t}$. Compute the residuals $\left(\hat{\varepsilon}_{t}\right)$ and the sum of square residuals $S S R_{0}=\sum_{t}^{T} \hat{\varepsilon}_{t}^{2}$.

2. Estimate the auxiliary regression of $\hat{\varepsilon}_{t}$ on $x_{t}$ and $\tilde{x}_{t} y_{t-1}^{i}, i=1,2,3$, and compute the sum of squared residuals from this regression $S S R_{1}$.

3. The $L M_{F}$ statistic can now be computed as

$$
L M_{F}=\frac{\left(S S R_{0}-S S R_{1}\right) / 3 p}{S S R_{1} /(T-4 p-1)}
$$

which under the null hypothesis has approximately an F distribution with $3 p$ and $(\mathrm{T}-4 \mathrm{p}-1)$ degrees of freedom. $\mathrm{p}$ is equal to the number of explanatory variables in the linear model.

Table: 2

LM Type Linearity Tests

\begin{tabular}{ccc}
\hline Lag $\backslash$ Variable & $f d i_{t}$ & $t$ \\
& & $t, 258(0,028)$ \\
2 & $1,846(0,075)$ \\
3 & $0,758(0,640)$ \\
4 & $1,918(0,063)$ \\
5 & $0,716(0,677)$ \\
6 & $1,250(0,276)$ \\
7 & $1,632(0,122)$ \\
9 & $1,329(0,235)$ \\
10 & $2,309(0,024)$ \\
11 & $3,216(0,002)$ \\
12 & $2,528(0,014)$ \\
\hline
\end{tabular}

\footnotetext{
* The data in parentheses indicate the probability values.
}

The linearity test shows the best transition variable which has the lowest p-value. In this study, the dynamics of the exchange rate effect on FDI is investigated so that the linearity test for real exchange rate is neglected. Thirteen $L M_{F}$ tests are performed for the 
possible transition variables by testing the dependent variable. As a result of these tests, the variables with the lowest $\mathrm{p}$-value (statistically most significant) are chosen as the transition variable. Test results are given in Table 2.

Equation (3.2) is used to determine whether the model is LSTAR or ESTAR. Once the transition variable is agreed upon $\mathrm{F}$ tests are applied in order to determine the appropriate transition function (Terasvirta, 1994: 211-212).

$$
\begin{aligned}
& H_{03}: \beta_{3}=0 \\
& H_{02}: \beta_{2}=0 / \beta_{3}=0 \\
& H_{01}: \beta_{1}=0 / \beta_{2}=\beta_{3}=0
\end{aligned}
$$

After the tests, the choice of LSTAR or ESTAR models is determined according to the following criterias:

1-If the model is LSTAR parameter $\beta_{3}$ is different than zero. If the model is ESTAR than the parameter is zero.

2-If the model is LSTAR than $\phi_{1,0}=\phi_{2,0}, \mathrm{c}=0$ and $\beta_{2}$ is zero. However, if the model is ESTAR, parameter $\beta_{2}$ is different than zero.

3-If the model is ESTAR $\phi_{1,0}=\phi_{2,0}, \mathrm{c}=0$ and $\beta_{1}$ is zero. But if the model is LSTAR, $\beta_{1}$ is different than zero.

Terasvirta (1994: 212) summarized the abovementioned criteria as follows; the model is ESTAR if the result of the $\boldsymbol{H}_{02}$ test's p-value turns out to be the smallest, otherwise LSTAR model's transition variable should be selected as LSTAR in all other cases.

Table: 3

\section{Selection of the Transition Function (Dependent Variable)}

\begin{tabular}{ccc}
\hline $\boldsymbol{H}_{03}$ & $\boldsymbol{H}_{\mathbf{0 2}}$ & $\boldsymbol{H}_{\mathrm{O1}}$ \\
\hline 1,318 & 0,861 & 3,287 \\
$(0,253)$ & $(0,490)$ & $(0,013)$ \\
\hline
\end{tabular}

As a result, the LSTAR model is selected for the dependent variable. Hence, in the nonlinear model, first order logistic function will be used as the transition function.

As mentioned before, the selection of the initial values that will be used in the estimation method is very important. In order to select these initial values, the value of the $\gamma$ parameter is altered in 0,1 increments between the interval $[1,500]$ and the $c$ parameter's value is altered again in 0,1 increments between the minimum and maximum values of 
transition variable. The $\gamma$ and $c$ parameters that minimize the variance of the error terms, are calculated as 650 and 17,774 respectively for the LST-ARDL model.

Estimation results of the realized LST-ARDL model are given in Eq. (3.6).

$$
\begin{aligned}
& f d i_{t}=\left(\begin{array}{c}
0,756 \\
(10,818)
\end{array} d i_{t-5}+\underset{(3,503)}{0,041 \text { reer }_{t-8}}\right)\left[1-\mathrm{G}\left(s_{t} ; \gamma, c\right)\right] \\
& \quad+\mathrm{G}\left(s_{t} ; \gamma, c\right)\left(\underset{(8,319)}{0,605} f d i_{t-5}+\underset{(5,219)}{0,063 \text { reer }_{t-8}}\right)+e_{t} \\
& \mathrm{G}\left(s_{t} ; \gamma, c\right)=\left(1+\exp \left[-650\left(f d i_{t-12}-\underset{(8431,104)}{18,054)}\right]\right)^{-1}\right. \\
& \mathrm{AIC}=4,486, \mathrm{SIC}=4,603, \mathrm{JB}=1,750(0,417), \operatorname{ARCH}(1)=0,004(0,951), \mathrm{ARCH}(4)=2,150 \\
& (0,708)
\end{aligned}
$$

*the $t$-statistics are given in parentheses.

From the estimation results given above, residuals that are not normally distributed in the linear model, turn out to be normally distributed according to the Jarque-Bera test statistics after applying the non-linear LST-ARDL model. The problem of heteroscedasticity emerging in the linear model has been removed with this nonlinear model.

According to the results obtained in the study, the threshold value is estimated as 18.054 million Dollars in the LST-ARDL model where $12^{\text {th }}$ lag of the dependent variable is used as the transition variable. As FDI falls below this threshold, that is, in the low FDI regime (or lower regime), the increase in foreign exchange rate increases FDI. Hence, equation (3.6) becomes $f d i_{t}=0,756 f d i_{t-5}+0,041$ reer $_{t-8}$ when $f d i_{t-12}<18,054$ and $G\left(s_{t} ; \gamma, c\right) \rightarrow 0$. The coefficient showing the effect of exchange rate on FDI is 0.041 and statistically significant at $1 \%$ level. As FDIs exceed the threshold of 18.054 , that is, they are in the regime of high direct foreign investment (or upper regime), the effect of foreign exchange rate on FDI is again positive. Hence, equation (3.6) becomes $f d i_{t}=1,761 \mathrm{fdi}_{t-5}+0,104$ reer $_{t-8}$ when $f d i_{t-12}>18,054$ and $G\left(s_{t} ; \gamma, c\right) \rightarrow 1$. The coefficient showing the effect of exchange rate on FDI is 0,104 and statistically significant at $1 \%$ level. This result indicates that the positive effect of real effective foreign exchange rate on FDI is higher in the upper regime. Therefore, in both regimes, only when the Turkish lira appreciates in real terms, Turkey experiences an increase in FDI inflow. In addition, when foreign direct capital inflow to Turkey is higher than the threshold value, the appreciation of the national currency increase the direct investment inflows of foreign capital substantially.

After the estimation of the model, the suitability of the model is also tested. Diagnostic tests proposed by Eitrheim and Teräsvirta (1996) are applied. These tests are as 
follows: remaining autocorrelation, remaining nonlinearity and parameter constancy tests. The results of these tests are given in Tables 4 and 5 .

Table: 4

Remaining Autocorrelation Test Results

\begin{tabular}{ccc}
\hline lag & Result of LM test $\left(f d i_{t-12}\right)$ & p value $\left(f d i_{t-12}\right)$ \\
\hline 1 & 0,415 & $(0,522)$ \\
2 & 0,806 & $(0,453)$ \\
3 & 1,676 & $(0,188)$ \\
4 & 1,781 & $(0,156)$ \\
5 & 1,724 & $(0,161)$ \\
6 & 1,635 & $(0,179)$ \\
7 & 1,644 & $(0,178)$ \\
8 & 1,732 & $(0,162)$ \\
9 & 1,382 & $(0,289)$ \\
10 & 1,216 & $(0,389)$ \\
11 & 0,712 & $(0,704)$ \\
\hline
\end{tabular}

Table: 5

Remaining Nonlinearity and Parameter Constancy Test Results

\begin{tabular}{|c|c|c|c|c|c|}
\hline Candidate variable & $\begin{array}{l}\text { Result of } \\
\text { LM test }\end{array}$ & $\mathrm{p}$ value & Candidate variable & $\begin{array}{l}\text { Result of } \\
\text { LM test }\end{array}$ & $\mathrm{p}$ value \\
\hline$f d i_{t}$ & & & reer $_{t}$ & & \\
\hline 1 & 0,918 & $(0,599)$ & 1 & 0,956 & $(0,546)$ \\
\hline 2 & 1,092 & $(0,372)$ & 2 & 1,001 & $(0,486)$ \\
\hline 3 & 1,078 & $(0,388)$ & 3 & 0,982 & $(0,511)$ \\
\hline 4 & 0,974 & $(0,522)$ & 4 & 1,170 & $(0,288)$ \\
\hline 5 & 0,887 & $(0,642)$ & 5 & 1,364 & $(0,140)$ \\
\hline 6 & 0,889 & $(0,640)$ & 6 & 1,040 & $(0,435)$ \\
\hline 7 & 0,995 & $(0,494)$ & 7 & 0,947 & $(0,559)$ \\
\hline 8 & 0,873 & $(0,662)$ & 8 & 0,886 & $(0,643)$ \\
\hline 9 & 0,880 & $(0,653)$ & 9 & 1,039 & $(0,436)$ \\
\hline 10 & 1,140 & $(0,318)$ & 10 & 1,029 & $(0,450)$ \\
\hline 11 & 0,929 & $(0,584)$ & 11 & 0,991 & $(0,499)$ \\
\hline 12 & 0,980 & $(0,514)$ & 12 & 0,928 & $(0,585)$ \\
\hline \multicolumn{6}{|c|}{ Parameter Constancy Test Result } \\
\hline & & & $0,938(0,571)$ & & \\
\hline
\end{tabular}

Diagnostic tests, do not indicate any problems with the 2-regime LST-ARDL. The LM test statistics show that there are no remaining autocorrelation and remaining nonlinearity in the estimated model. In addition, the parameter constancy is tested by the 'time-dependent variable coefficient test' in Table 5. These results provide no support for multiple regime STR models and show that the estimated model is satisfactory.

\section{Conclusion}

In this study, the effect of the real exchange rate on FDIs during the 2005:1 - 2016:12 period is examined for Turkey in the context of linear and nonlinear models (STR-ARDL model). It has been revealed that the foreign exchange rate, which is found to have a positive but a very low impact on FDIs in the linear model, is proven to be much more influential on FDIs provided that a correct model is specified with an asymmetric logistic function that has two different regimes. In the upper regime - when the foreign investment inflow is high- the positive effect of the real exchange rate on FDIs is found to be greater than the lower regime. When the inflow of foreign investment is low, however, the positive and significant effect 
of real exchange rate on FDI is less. The high valued exchange rate parameter, which is not available in the linear model, is statistically significant when divided into a lower regime and an upper regime in the nonlinear model. Regarding the exchange rate, the coefficients are higher compared to the linear model.

The absence of time-dependent parameter effect indicates that there is no structural break between these two variables in the period observed. In this sense, the state dependent nonlinear structure is the best way to model the relationship between these two variables. The threshold value corresponds to a FDI inflow of 18 million Dollars. If the foreign capital inflow occurs below the threshold, the model identifies it as the low investment inflow regime. If the foreign capital inflow is above the threshold it is defined as the high investment inflow regime. In this regard the appreciation of the Turkish Lira whets potential investors' appetite for investing in both the lower and upper regime but the effect in the upper regime is higher. Indeed, in the upper regime, when the investment inflows are already high, the contribution of the exchange rate to existing foreign investments is greater than the low inflow regime. As a result the true nature of the relationship between these two variables is estimated accurately when a nonlinear model is used.

In sum, the first conclusion of the study is that FDIs increase when TL appreciates. Thus for Turkey to attract FDI it should maintain a stable political and economic environment that leads to a strong Turkish lira vis-a-vis other currencies. Second, relationship between investment inflow and exchange rate should not be estimated using the linear model. The second conclusion is that there is no structural break in the period studied. Lastly the state dependent nonlinear structure is the best way to model the relationship between the examined two variables.

Finally, if a policy maker is to evaluate the estimates derived from this study, the following policy proposal can be made: When FDI is either above or below 18 million Dollars threshold, the appreciation of the Turkish Lira in the floating exchange rate regime will have a similar but not an identical effect on the investment inflow. Therefore more effective policies can be proposed if the policy makers have the relevant information about the relationship threshold.

\section{References}

Baek, I.M. \& T. Okawa (2001), "Foreign Exchange Rates and Japanese Foreign Direct Investment in Asia", Journal of Economics and Business, 53(1), 69-84.

Bayoumi, T. \& G. Lipworth (1998), "Japanese Foreign Direct Investment and Regional Trade”, Journal of Asian Economics, 9(4), 581-607.

Benassy-Quere, A. \& L. Fontagne \& A. Lahreche-Revil (2001), "Exchange Rate Strategies in the Competition for Attracting FDI", Papiers d'Economie MathÄ Cmatique et Applications

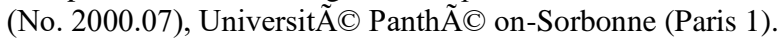

Blonigen, B.A. (1997), "Firm-Specific Assets and the Link Between Exchange Rates and Foreign Direct Investment", The American Economic Review, 87(3), 447-465. 
Cambazoğlu, B. \& S. Günes (2016), “The Relationship between Foreign Exchange Rate and Foreign Direct Investment in Turkey", Economics, Management and Financial Markets, 11(1), 284-293.

Caves, R.E. (1989), "Exchange-rate Movements and Foreign Direct Investment in the United States", in: D.B. Audretsch \& M.P. Claudon (eds.), The internationalization of U.S. markets, New York: New York University Press.

Central Bank of the Republic of Turkey (2013), Monetary Transmission Mechanism, <http://www.tcmb.gov.tr/wps/wcm/connect/4e99834e-179b-4a08-820cf2b259032afd/ParasalAktarim.pdf?MOD=AJPERES\&CVID=>, 20.02.2018.

Chakrabarti, A. (2003), "A Theory of the Spatial Distribution of Foreign Direct Investment", International Review of Economics and Finance, 12(2), 149-169.

Çorakc1, A. \& T. Omay \& F. Emirmahmutoğlu (2017a), "Re-examing the Real Interest Rate Parity Hypothesis (RIPH) Using Panel Unit Root Tests with Asymmetry and Cross-section Dependence", Empirica: Journal of European Economics, 44(1), 91-120.

Çorakc1, A. \& T. Omay \& F. Emirmahmutoğlu (2017b), "PPP Hypothesis and Temporary Structural Breaks", Economics Bulletin, 37(3), 1541-1548.

Dewenter, K.L. (1995), “Do Exchange Rate Changes Drive Foreign Direct Investment?”, Journal of Business, 68(3), 405-433.

Eitrheim, Ø.\& T. Teräsvirta (1996), “Testing the Adequacy of Smooth Transition Autoregressive Models", Journal of Econometrics, 74(1), 59-75.

Enders, W. (2008), Applied Econometric Time Series, John Wiley \& Sons Inc., $3^{\text {rd }}$ edition.

Froot, K. \& J. Stein (1991), "Exchange Rates and Foreign Direct Investment: An Imperfect Capital Markets Approach”, Quarterly Journal of Economics, 106(4), 1191-1217.

Goldberg, L.S. \& M.W. Klein (1999), "International Trade and Factor Mobility: An Empirical Investigation", National Bureau of Economic Research Discussion Paper, no. w7196.

Harris, R.S. \& D. Ravenscraft (1991), "The Role of Acquisitions in Foreign Direct Investment: Evidence from the US Stock Market", The Journal of Finance, 46(3), 825-844.

Hasanov, M. \& T. Omay (2008), "Nonlinearities in Emerging Stock Markets: Evidence from Europe's Two Largest Emerging Markets”, Applied Economics, 40(20), 2645-2658.

Ito, T. (2000), "Capital flows in Asia", in: S. Edwards (ed.), Capital Flows and the Emerging Economies: Theories, Evidence and Controversies, Chicago: University of Chicago Press. 255-296.

Karagöz, K. (2007) “Türkiye'de Doğrudan Yabancı Yatırım Girişlerini Belirleyen Faktörler: 19702005”, Journal of Yasar University, 2(8), 927-948.

Kiyota, K. \& S. Urata (2004), "Exchange Rate, Exchange Rate Volatility and Foreign Direct Investment", The World Economy, 27(10), 1501-1536.

Klein, M.W. \& E. Rosengren (1994), "The Real Exchange Rate and Foreign Direct Investment in the United States: Relative Wealth vs. Relative Wage Effects”, Journal of International Economics, 36(3-4), 373-389.

Lin, C.F.J. \& T. Teräsvirta (1994), "Testing the Constancy of Regression Parameters against Continuous Structural Change", Journal of Econometrics, 62(2), 211-228.

Omay, T. \& M. Hasanov (2010), "Türkiye için Reaksiyon Fonksiyonunun Doğrusal Olmayan Modelle Tahmin Edilmesi”, Çankaya University Journal of Humanities and Social Sciences, 7(2), 467-490. 
Omay, T. \& B. Araz-Takay \& A. Eruygur \& İ. Kılıç (2013), "The Effects of Terrorist Activities on Foreign Direct Investment: Nonlinear Evidence from Turkey", Review of Economics, 64(2), 139-158.

Omay, T. \& A. Çorakcı \& F. Emirmahmutoğlu (2017), "Real Interest Rates: Nonlinearity and Structural Breaks", Empirical Economics, 52(1), 283-307.

Sazanami, Y. \& S. Yoshimura \& K. Kiyota (2003), "Japanese Foreign Direct Investment to East Asia and Exchange Rate Policies: Some Longer Term Policy Implications after the Crisis", Keio Economic Studies, 40(1), 1-26.

Sollis, R. (2009), “A Simple Unit Root Test against Asymmetric STAR Nonlinearity with an Application to Real Exchange Rates in Nordic Countries", Economic Modelling, (26), 118-125.

State Planing Organization (2000), Doğrudan Yabancı Sermaye Yatırımları Özel İhtisas Komisyonu Raporu, Ankara.

Stevens, G.V.G. (1998), "Exchange Rates and Foreign Direct Investment: A Note”, Journal of Policy Modeling, 20(3), 393-401.

Swenson, D. (1994), "Impact of US Tax Reform on Foreign Direct Investment in the United States", Journal of Public Economics, 54(2), 243-266.

Takagi, S. \& Z. Shi (2011), "Exchange Rate Movements and Foreign Direct Investment (FDI): Japanese Investment in Asia, 1987-2008”, Japan and the World Economy, 23(4), 265272.

Teräsvirta, T. (1994), "Specification, Estimation, and Evaluation of Smooth Transition Autoregressive Models", Journal of the American Statistical Association, 89(425), 208218.

van Dijk, D. (1999), “Smooth Transition Models: Extensions and Outlier Robust Inference”, PhD Thesis, Erasmus Universiteit Rotterdam.

van Dijk, D. \& T. Teräsvirta \& P.H. Franses (2000), "Smooth Transition Autoregressive Models-A Survey of Recent Developments", Econometric Reviews, 21(1), 1-47.

Yapraklı, S. (2006), “Türkiye'de Doğrudan Yabancı Yatırımların Ekonomik Belirleyicileri Üzerine Ekonometrik Bir Analiz”, Dokuz Eylül Üniversitesi İ̈BF Dergisi, 21(2), 23-48.

Yılgör, M. \& A. Serel \& M.E. Erçakar (2011), "Doğrudan Yabancı Yatırımların Gelişini Etkileyen Faktörler: Türkiye Üzerine Bir Model”, Balıkesir Üniversitesi Sosyal Bilimler Enstitüsü Dergisi, 14(26), 119-131. 
Erünlü, Z. (2018), "Do Depreciations Really Trigger an Inflow of Foreign Direct Investment? The Case of Turkey", Sosyoekonomi, Vol. 26(37), 257-272. 